\title{
Mediācijas piemērošanas iespējas veselības aprūpes jomā
}

\author{
Karina Palkova \\ Rīgas Stradiña universitāte, Juridiskā fakultāte, \\ Tiesību zinātñu katedra, Latvija \\ karina.palkova@inbox.lv
}

\section{Kopsavilkums}

Rakstā aplūkota mediācijas procesa piemērošana strīdos starp pacientiem un ārstniecības personām veselības aprūpes jomā. Mediācija ir salīdzinoši jauns ārpus tiesas strīdu izskatǐšanas process Latvijā, taču plaši izplatîts Eiropas valstīs. Saskañā ar šobrīd spēkā esošajiem tiesību aktiem strīdi, kas rodas starp pacientiem un ārstniecības personām, galvenokārt tiek risināti vispārējas jurisdikcijas tiesās. Prakse rāda, ka pieteikumu skaits par nekvalitatīvi sniegtajiem medicinas pakalpojumiem aug. Par to liecina Latvijas tiesas spriedumu un Eiropas Cilvēktiesību tiesas spriedumu skaits.

Latvija ir zaudējusi vairākas medicinas tiesību jomā Eiropas Cilvēktiesību tiesā izskatītas lietas $[9,10,11]$. Tas norāda uz virkni problēmu Latvijas veselības aprūpes tiesību nozarē. Lai izvērtētu strīdu starp pacientiem un ārstniecỉbas personām un gūtu ātrāku un kvalitatīvāku iespējamo risinājumu, nepieciešams izvērtēt mediācijas piemērošanu strīdos veselības aprūpes jomā. Pētỉjuma rezultāti ḷauj secināt, ka tiesību normu saturs piel̦auj mediācijas piemērošanu medicīnas tiesību jomā, taču, lai mediācijas process pilnvērtīgi darbotos, nepieciešams ievērot priekšnoteikumus, kas tiks pētìti darbā.

Atslēgvārdi: mediācija, medicīnas tiesības, veselības aprūpe.

\section{levads}

Latvijā arvien vairāk rodas strīdi starp pacientiem un ārstniecības personām. Par to liecina tiesvedības procesu skaitliskais pieaugums pacientu tiesību aizsardzības jomā ne tikai Latvijā, bet arī Eiropā. Vienlaikus jāatzīmē, ka iepriekšminēto tiesvedības procesu skaits Latvijā joprojām ir proporcionāli daudz mazāks nekā citās Eiropas Savienības valstīs. Tas norāda ne tikai uz pacientu neapmierinātību ar veselības aprūpes nozares sniegtajiem pakalpojumiem un to kvalitāti, bet arī uz tās trūkumiem. 
Saskaṇā ar Primārās veselības aprūpes attīstības plānu 2014.-2016. gadam, ko izstrādājusi Veselības ministrija, pacienti nav apmierināti ar Latvijas veselības aprūpes kvalitāti. Jāuzsver arī, ka Latvijā pastāvošais tiesiskais regulējums vairāku iemeslu dēl ierobežo pacientu brīvības un iespējas strīdu risināšanas gadỉjumā.

Savukārt tiesiskais regulējums pilnā mērā neaizsargā arī ārstniecības personas. Normatīvajos aktos pastāv virkne nepilnību, kas sarežği arī tiesāšanās procesu starp pusēm, neveicinot strīdu ātrāku risināšanu vai strīdu novēršanu. N̦emot vērā biežās izmaiṇas medicīnas tiesību jomu regulējošajos normatīvajos aktos, jautājums ir par labvēlīgo attiecību veidošanu starp pacientu un veselības aprūpes pakalpojumu sniedzēju. Ārstniecības personas var nebūt laikus informētas par jaunajām izmaiṇām likumos, un tādējādi var rasties zināmi riski attiecībās ar pacientiem. Ne vienmēr ir skaidri nosacījumi pacientu tiesību piemērošanas jomā, kas var radīt domstarpības tiesību normu interpretācijā. Savukārt lietu izskatǐ̌anas stadijā vispārējās jurisdikcijas tiesās pacientiem trūkst tiesiskās paḷāvības un pārliecības par tiesu vai sagatavoto ekspertu slēdzienu objektivitāti.

Pētījums skar šauru jomu, kas līdz šim nav aprakstìta zinātniskajā literatūrā. Tā novitāti veido pacientu un ārstniecíbas personu tiesisko attiecỉbu izpēte, kas balstās uz mediācijas procesa piemērošanas iespēju strīdos starp pacientiem un ārstniecības personām. Pētnieciskā darba rezultātā tiks piedāvātas minēto strīdu izskatǐšanas iespējas un pacientu tiesību aizsardzības mehānisma pilnveidošana.

\section{Darba mērķis}

Darba mērkis ir izpētìt mediācijas procesa piemērošanas iespēju strīdos starp pacientiem un ārstniecības personām, kā arī noskaidrot priekšnoteikumus mediācijas procesa veiksmīgai ieviešanai.

\section{Metodes}

Zinātniski pētnieciskās metodes, kas izmantotas mērḳa sasniegšanai, ir analīze, lai noskaidrotu pētāmā objekta struktūru, un log̣iskā metode, ar kuras palīdzību tiek analizētas mediācijas piemērošanas efektivitāte strīdos starp pacientiem un ārstniecības personām.

Veselïbas aprūpes joma ir pakḷauta sarežgitam tiesiskam regulējumam. Veselïbas aprūpes pamatā ir tāda vērtība kā cilvēka dzìve, kas tiek aizsargāta, tostarp ar ANO Vispārējo Cilvēktiesību deklarāciju [2]. Medicīnas tiesību jomā tiek skartas cilvēka tiesības uz dzìvību un veselību. Tādējādi nozare ir viena no sarežgìitākajām un tiek raksturota ar lielu strīdu skaitu. Strīdi starp pacientiem un ārstniecības personām ir emocionāli, kas tomēr var tikt novērsti ārpus tiesas, proti, savstarpējas komunikācijas līmenī [5]. İpaša uzmanība jāvērš uz destruktīvo emociju neitralizēšanu un konflikta patieso iemeslu noskaidrošanu. 
Viens no veidiem šādu strīdu risināšanā ir mediācijas process, kas, pamatojoties uz 2008. gada 21. maija Eiropas Padomes direktīvu 2008/52/EK par konkrētiem mediācijas aspektiem civillietās un komerclietās, tika implementēts Latvijas likumdošanā. 2014. gadā pieṇemts Mediācijas likums [4], un tādējādi Latvijas normatīvais regulējums ir sniedzis iespēju piemērot alternatīvo strīdu risināšanas metodi - mediāciju.

Mediācijas likuma [4] 1. pants skaidri nosaka, ka mediācija ir brīvprātīgais sadarbības process, kurā puses cenšas panākt pien,emamu vienošanos, lai atrisinātu savas domstarpības. Procesu vada mediators. Mediācijas likuma 2. panta otrajā daḷā norādìts, ka mediāciju var izmantot gan ārpustiesas procesā, gan arī tiesvedības procesā, ja tiesību normas nenosaka citādi. Civillikuma [3] 23. pants nosaka, ka visi civiltiesiskie strīdi ir pakḷauti tiesai. Taču tas neatṇem tiesības pusēm savstarpēji vienoties par strīda izšḳiršanu, izmantojot mediāciju. Tas nozīmē, ka normatīvais regulējums ir sakārtojis normatīvo bāzi, paverot ceḷu alternatīviem strīdu risināšanas modeḷiem arī strīdos starp pacientiem un ārstniecības personām vai medicīnas iestādēm.

Mediācijas process sekmē emocionālā aizskāruma cēloṇu atklāšanu ar problēmas turpmāku tiesisku risināšanu. Loǵisks ir pieņēmums - lai rastu racionālu strīda risinājumu, jāveic visas iespējamās darbības, kas mazinātu sākotnējo emocionālo spriedzi pušu starpā. Izpētot mediācijas procesa principus un metodes, izriet, ka mediācija ir tieši saistīta ar iepriekš norādīto log̣isku strīdu risināšanu.

Mediācijas piemērošana veselības aprūpes jomā varētu kalpot ne tikai kā strīdu izskatīšanas mehānisms ārpus tiesas stadijā, bet arī laikus identificēt sistēmiskās kḷūdas vai trūkumus, kas rodas veselības aprūpes jomā pacientu un ārstniecības personu tiesiskas komunikācijas rezultātā.

Mediācija ietver sevī l,oti komplicētu risinājumu, kas lielākoties var tikt raksturots ar vairākām specifiskām tiesiskām pazīmēm. Veselības aprūpes nozare ir sarežğīita tiesiskā kategorija, kas iekḷauj sevī l̦oti dažādu profesionālu darbību kopumu medicīnas pakalpojumu sniegšanas jomā. Tā sastāv no sarežğìtu procesu virknes, piemēram, medicīnas ekspertīzes, profilakses pasākumiem, orgānu un šūnu transplantācijas. Papildus jāatzīmē arī tādas īpatnības kā katra pacienta individuālais veselības stāvoklis, organisma ippatnības un reakcijas uz dažāda veida manipulācijām. Strīdu objekts starp pacientiem un ārstniecības personām lielākoties ir sniegto pakalpojumu kvalitāte, kas ir grūti izmērāma, n,emot vērā vairākus medicīniska rakstura rādītājus [12].

Tiesu prakse liecina, ka strīdi starp pacientiem un ārstniecības personām rodas arī tāpēc, ka nav pieejama medicīniskā dokumentācija vai tajā tiek iekḷauta nepilnīga informācija, kā arī ar ārstniecības personām noslēgto līgumu satura dēḷ. Tādējādi veiksmīga mediācijas procesa piemērošana strīdos starp pacientiem un ārstniecības personām ir tieši saistīta ar neatkarīgas medicīnas ekspertīzes kvalitāti minētajos strīdos. Pacientam jābūt pilnīgi un neapšaubāmi pārliecinātam par eksperta veikto atzinumu. Atzinumam jābūt objektīvam, pilnīgam un kvalitatīvam. Kaut gan strīds var tikt skatīts mediācijas procesā, ekspertu slēdzieni būs viens no pamatnoteikumiem veiksmīga procesa norisē [8]. 
Vienlaikus ne mazāk svarīga nozìme strīdos starp pacientiem un ārstniecības personām vai medicīnas iestādēm ir komunikācijas trūkumam un pacientu un ārstniecības personāla informètîbai [7]. Komunikācijas prasme ir viens no veiksmīgas mediàcijas procesa piemērošanas priekšnoteikumiem.

Arī Pacientu tiesību likuma [6] 2. pants nosaka, ka ir jāveicina labvēlīgas attiecības starp pacientu un veselïbas aprūpes pakalpojumu sniedzēju. Papildus ir jāsekmē pacienta aktīva lìdzdalība veselības aprūpē un jānodrošina viṇam iespēja îstenot un aizstāvēt savas tiesības un intereses [6]. No tā, cik kvalitatīvi ārstniecības personas spēj izklāstìt pacientam svarīgu un nepieciešamu informāciju, atkarīgs pacienta lēmums, vai viňš izvēlēsies brīvprātīgi piedalīties mediācijas procesā.

Veicot kvalitatīvu komunikāciju, ārstniecības personas izglīto pacientu, tādējādi sniedzot viņam iespēju pastarpināti līdzdarboties ārstniecības gaitā un būt informètam. Izglìtošanas rezultātā pacients sāk saprast veselības aprūpes sistēmu. Tas savukārt samazina potenciālo tiesvedību skaitu un palielina mediācijas procesa piemērošanas iespējas. Turpretī tiesāšanās ir ḷoti vājš komunikācijas posms, un iznākumā viena puse vienmēr būs neapmierināta, tādējādi pieḷaujot citu tiesvedību lielu varbūtību. Cits jautājums ir ārstniecības personu pienākums paust patiesību. Vienlaikus jāuzsver, ka ārstniecíbas personas l̦oti reti būs atvērtas tiesvedības procesa gaitā, jo galvenais uzdevums ir labvēlīgs spriedums. Papildu informācijas izpaušana var ietekmēt procesa iznākumu. Tādējādi, piemērojot mediācijas procesu starp pacientiem un ārstniecības personām, jāmaina gadiem ilgi izveidojies strīdu risināšanas modelis.

Mediācijas process balstās uz brīvprātības principa. Taču līgumos, kas tiek slēgti starp ārstniecības personu un pacientu, joprojām lielākoties tiek paredzēta strīdu izskatī̌ana vispārējās jurisdikcijas tiesās. Tātad tas, vai mediācijas process veselības aprūpes jomā tiks pieņemts un aktīvi izmantots veselības aprūpes strīdos, atkarīgs tikai un vienīgi no ārstniecības personas, kas sagatavo līgumus starp sevi un pacientiem.

Viens no mediācijas pamatprincipiem ir konfidencialitāte [5]. Tātad mediācijas procesa piemērošana veselïbas aprūpes strīdos aizsargā ārstniecības personu no informācijas izpaušanas. Strīds, kas tiek skatīts mediācijas ceḷā, ir konfidenciāls, turpretī, risinot strīdu vispārējās jurisdikcijas tiesā, pien,emtais nolēmums ir publisks.

Iepriekš minētais sniedz iespēju rast vispārēju priekšstatu par mediāciju un strīdiem veselības aprūpes nozarē. Taču jāuzsver, ka, ņemot vērā komplicēto veselības aprūpes tiesisko būtību, arī mediācijas process nevar būt piemērots visos starp pacientu un ārstniecības personu radušos strīdos. Kā izṇēmums jāmin, piemēram, gadỉjumi, kad tiek ierosināta krimināllieta.

\section{Secinājumi}

Strīdi veselības aprūpes sistēmā ir lıti komplicēti. Pacientiem un ārstniecības personām, nonākot konfliktsituācijā, vairākums gadỉjumos (izṇemot normatīvajos aktos minētos iznēēmumus, piemēram, krimināllietas) ir tiesības izvēlēties konflikta risināšanas veidus. 
Pacienti izvēlēsies mediāciju tikai gadījumā, ja sistēma pierādīs, ka ir spējīga darboties efektīvi.

Sistēmas efektivitāte ir atkarīga galvenokārt no ḷoti pārdomātas mediācijas ekonomiskās pieejamības, kas ne vienmēr ir ekonomiski izdevīgāks risinājums pacientam salīdzinājumā ar strīdu izskatīšanu vispārējas jurisdikcijas tiesās.

Mediācijas piemērošana strīdos starp pacientiem un ārstniecības personām ir atkarīga no pacientu un ārstniecības personu iniciatīvas. Ārstniecības iestādēm ir dots tiesiskais pilnvarojums piemērot mediāciju vairākos gadījumos. Taču ir nepieciešams veikt saturiskas izmaiñas ārstniecības personu iekšējos normatīvajos aktos. Piemēram, jāparedz strīdu risināšanas iespēja ar mediācijas procesa palīdzību.

Darbs tapis doktora studiju programmas "Juridiskās zinātnes" promocijas darba "Pacienta un ārstniecības personu, medicinas iestāžu tiesisko attiecību regulējuma problemātika: starptautiskais aspekts un modernizācijas virzieni” izstrādes gaitā.

\section{Opportunity to Use Mediation in Healthcare Disputes}

\section{Abstract}

The aim of the article is to provide some insight into an opportunity to use mediation in healthcare disputes in Latvia. Mediation is the process or form of alternative dispute resolution. Mediation is not yet popular in Latvia but in Europe the process has gained strong background. The number of applications in healthcare cases before the court are growing. It shows that there are some problems in healthcare legal system that should be improved. The article highlights the practical side of the problem to use mediation in disputes between patients and medical persons, as well as relationships and communication problems between both parties.

The results of the research show that legislation allows applying mediation in healthcare disputes. Nevertheless, in order to make mediation process more popular in that particular sphere, it is necessary to comply with several conditions.

Keywords: mediation, healthcare, medicine law.

\section{Literatūra}

1. Ārstniecības likums. Iegūts no: http://likumi.lv/doc.php?id=44108 [sk.13.10.2015.].

2. Cilvēka tiesību un pamatbrīvību aizsardzības konvencija. Iegūts no: http://likumi.lv/doc. php?id=43859 [sk. 11.10.2015.].

3. Civillikums. Iegūts no: http://likumi.lv/doc.php?id=225418 [sk. 10.10.2015.].

4. Mediācijas likums. Iegūts no: http://likumi.lv/doc.php?id=266615 [sk. 14.10.2015.]. 
5. Mediācija. Mediācijas pamati teorijā un praksē. VAS “Tiesu namu aǵentūra”, 2007, 136.-140. lpp.

6. Pacientu tiesību likums. Iegūts no: http://likumi.lv/doc.php?id=203008 [sk. 13.10.2015.].

7. Bolis, J. Mediācija. Juridiskā koledža, 2007, 11.-16. lpp.

8. Broekman, J. M. Normative systems in legal and moral theory. Duncker \& Humblot, 1997.

9. Case of A.k. vs. Latvia. Iegūts no: http://hudoc.echr.coe.int/sites/eng/pages/search.aspx?i=001145005 [sk. 09.10.2015.].

10. Case of L.H. vs. Latvia. CASE OF L.H. v. LATVIA. Iegūts no: http://hudoc.echr.coe.int/sites/ eng/pages/search.aspx?i=001-142673 [sk. 12.10.2015.].

11. Case of Krivošejs vs. Latvija. Iegūts no: http://hudoc.echr.coe.int/sites/eng/pages/search. aspx?i=001-108665 [sk. 11.10.2015.].

12. Hall, M. A., Bobinski, M. A., Orentlicher, D. Medical Liability and Treatment Relationships. Aspen publishers, 2005. 